\title{
HUMAN RESOURCE PRACTICES AS PREDICTORS OF WORK-FAMILY OUTCOMES AND EMPLOYEE TURNOVER
}

\author{
September, 2001
}

\author{
ROSEMARY BATT \\ Cornell Employment and Family Careers Institute and \\ Department of Human Resource Studies \\ New York State School of Industrial and Labor Relations \\ Cornell University \\ Ithaca, NY 14853-3901 \\ Tel: (607) 254-4437 \\ Fax: (607) 255-1836 \\ Email: rb41@cornell.edu \\ P. MONIQUE VALCOUR \\ Cornell Employment and Family Careers Institute and \\ Department of Organizational Behavior \\ New York State School of Industrial and Labor Relations \\ Cornell University \\ Ithaca, NY 14853-3901 \\ Tel: (607) 257-0445 \\ Fax: (607) 255-1849 \\ Email:pmv6@cornell.edu
}

This paper was initially prepared for the conference "Work and Family: Expanding the Horizons," March 3-4, 2000, in San Francisco, sponsored by the Business and Professional Women's Foundation, the Center for Working Families at U.C. Berkeley, and the Alfred P. Sloan Foundation. A later version was presented at the 2000 Annual Meeting of the Academy of Management in Toronto. This study draws on data from the Cornell Careers Institute, with generous funding from the Alfred P. Sloan Foundation Grant \#96-6-9. We particularly thank Phyllis Moen for her on-going support, and George Milkovich for comments on prior drafts. 


\begin{abstract}
Drawing on a non-random sample of 557 dual-earner white collar employees, this paper explores the relationship between human resource practices and three outcomes of interest to firms and employees: work-family conflict, employees' control over managing work and family demands, and employees' turnover intentions. We analyze three types of human resource practices: work-family policies, HR incentives designed to induce attachment to the firm, and the design of work. In a series of hierarchical regression equations, we find that work design characteristics explain the most variance in employees' control over managing work and family demands, while HR incentives explain the most variance in work-family conflict and turnover intentions. We also find significant gender differences in each of the three models. Our results suggest that the most effective organizational responses to work-family conflict and to turnover are those that combine work-family policies with other human resource practices, including work redesign and commitment-enhancing incentives.
\end{abstract}




\section{HUMAN RESOURCE PRACTICES AS PREDICTORS OF WORK-FAMILY OUTCOMES AND EMPLOYEE TURNOVER}

Employee turnover has resurfaced as an important issue for firms in recent years as they face tight labor markets and skill shortages. The costs of turnover are high, particularly for technical, professional, and managerial employees, the subject of this study, because their skills and knowledge are difficult to replace (Cascio, 1991). At the same time, dual-earner families now constitute the typical American family, and fewer than one third of U. S. families fit the traditional profile of a married couple in which the wife does not work outside the home (U. S Council of Economic Advisers, 2000). As a result, the difficulty of managing work and family demands has increased for many working adults, and many employers have come to view "family-friendly" policies as an important attraction and retention strategy.

Formal work-family policies now encompass a wide range of programs including referral and financial resources for child and elder care, on-site child care, family leave, and flexible scheduling and work arrangements, including telecommuting. Employers' use of work-family policies has grown significantly in recent years, and this represents a continuation in the expansion of average benefit packages, which grew from 25 percent of total compensation in 1959 to over 42 percent in 1996 (Milkovich and Newman, 1999). Yet companies also are seeking ways to reduce, not expand, the cost of benefits; and in the current competitive and costconscious climate, human resource departments are under pressure to cost-justify their investments in new benefits. While a growing number of studies find that family-friendly policies benefit employees (see Lobel, 1999 for a review), empirical support for the business case for investing in work-family benefits is less developed (Friedman, 1991).

The central argument in this paper is that work-family policies are a necessary but insufficient strategy to help employees effectively manage work and family demands. While most employers focus on specific work-family policies (such as dependent care or flexible scheduling) to solve work-family dilemmas, we argue that they must consider a broad range of human resource practices as components of systems which, taken together, shape employees' 
capacity to meet work and family demands in an integrated fashion. The impact of access to flexible scheduling, for example, is not likely to affect excessive work hours, workloads, or "the time squeeze" -- the gap between the demands on individuals' time and the actual time they have (Bailyn, 1993a; Glass and Estes, 1997; Hochschild, 1997; Moen and Yu, 1999).

Our argument draws inspiration from research on "high involvement work systems" -research that has shown that it is not individual human resource practices alone, but coherent sets of practices that allow employees to work effectively. Several studies have shown that these systems predict better organizational performance (Becker and Gerhart, 1996; Ichniowski et al., 1996) and lower turnover (Arthur, 1994; Huselid, 1995; Shaw et al., 1998; Batt, 2000). The high involvement literature is limited, however, in that it has not included work-family policies as part of these HR systems, nor has it examined how these HR systems influence work-family outcomes (Perry-Smith and Blum, 2000). Also, it has focused primarily on production-level workers to the exclusion of technical, professional, and managerial employees.

In this paper, therefore, we examine a series of human resource practices that the high involvement literature indicates should reduce employee turnover, and we test whether these HR practices also help reduce work-family conflict or assist employees in managing the work-family interface. We compare the relative importance of three sets of polices: work-family policies, HR incentives designed to induce attachment and commitment (compensation, career development, and job security), and the design of work (including decision-making autonomy, participation in teams, and the use of flexible technologies). We examine outcomes of interest to employers (turnover intentions) as well as employees (their perceptions of work interference with family life and of their control over managing work and family demands). Finally, we compare the results for men and women in dual-earner families, as prior research shows that there are gender differences in work-family conflict (e.g., Becker and Moen, 1999; Duxbury, Higgins and Lee, 1994; Duxbury and Higgins, 1991; Gutek, Searle and Klepa, 1991). To examine these questions, we draw on a unique 1998 non-random survey of 557 primarily professional and managerial employees in dual-career couples. 


\section{PRIOR LITERATURE}

Because there are few studies that examine a broad set of human resource practices as they relate to work-family outcomes, our literature review draws on two streams of research. We first discuss the literature on work-family policies and then turn to the research on high involvement human resource systems.

\section{Work-Family Policies and Outcomes}

In this study, we conceive of outcomes of interest to employees in terms of work-family integration. By this we mean that employees do not experience work-family conflict and are able to integrate or successfully manage their work and family demands. The concept is similar to that of work-family balance, but does not imply the equality of spheres implicit in the concept of balance. In the existing work-family literature, there are two concepts that capture the notion of work-family integration: work-family conflict (e.g., the opposite of integration) and perceived employee control over managing work and family demands (Thomas and Ganster, 1995).

Work-family conflict can occur in two directions: work interference with family and family interference with work (Carlson, Kacmar and Williams, 2000; Greenhaus and Beutell, 1985; Gutek, Searle and Klepa, 1991). In the present study, we are primarily concerned with the ways in which work demands interfere with life at home and the ways in which human resource practices can mitigate those effects. Work-to-family conflict, which is also referred to as negative spillover from work to family or as work interference with family, has been shown to be related to both personal and work characteristics (Cooke and Rousseau, 1984; Frone, Russell and Cooper, 1992; Greenhaus et al., 1989; Parasuraman, Greenhaus and Granrose, 1992; Wallace, 1997).

Perceived control over managing work and family demands is related to the idea of integrating work and family demands. Control is defined as "the belief that one can exert some influence over the environment, either directly or indirectly, so that the environment becomes more rewarding or less threatening" (Thomas and Ganster, 1995:7). With respect to work-family concerns, Thomas and Ganster (1995) note that, for instance, having the ability to choose starting 
and ending times at work, being able to coordinate vacation times in order to meet family needs, and having the freedom to contact family members by phone while working can serve to increase the amount of control employees feel they have over managing their work and family demands and decrease the strain they experience in integrating those demands. Past research has found that such control is negatively related to work-family conflict and undesirable health outcomes and positively related to job satisfaction and desirable health outcomes (Adams and Jex, 1999; Thomas and Ganster, 1995).

\section{Dependent Care and Flexible Scheduling Policies}

Employer solutions to work-family conflict have focused heavily on specific work-family policies and practices, such as child care services or flexible scheduling. A useful distinction is between policies designed to provide care services (information and referral services, financing of child care or elder care, etc.) and those designed to create more flexible work arrangements (flexible schedules that permit flexible starting and quitting times, telecommuting, compressed workweeks, job sharing, etc.). There is a modest empirical literature on dependent care services, and two early studies showed that availability of day care (Youngblood and Chambers-Cook, 1984) and utilization of day care (Milkovich and Gomez, 1976) increased retention rates in the short term, but these studies did not explore long-term attachment to the firm. Other reviews of the literature have concluded that there is no credible research linking employer-sponsored child care to lower work-family conflict, absenteeism or turnover, or higher productivity (Goff, Mount and Jamison, 1990; Miller, 1984). A more recent study of employees with access to dependent care services also found no significant relationship between the availability of those services and work-family outcomes or absenteeism (Thomas and Ganster, 1995).

A much larger body of research has examined outcomes associated with flexible work arrangements, and it has documented significant positive outcomes for employees. Baltes and colleagues (1999) conducted a meta-analysis of 31 studies of flexible scheduling practices. They reported a significant relationship between flexible scheduling and employee outcomes (job satisfaction, satisfaction with scheduling) in 18 studies of flextime and 8 studies of compressed 
workweeks. Another meta-analysis established a consistent negative relationship between workfamily conflict and job and life satisfaction (Kossek and Ozeki, 1998), but the authors noted that researchers have generally failed to assess the relationship between work-family conflict and outcomes other than satisfaction.

The effectiveness of formal policies depends importantly on whether frontline supervisors will support their implementation (Christensen and Staines, 1990:462). In cases where employers view the use of work-family policies as an indicator of low commitment to work and career, supervisors may mitigate this unsupportive organizational norm by making it clear that using work-family benefits will not be held against the employees under their purview. Alternatively, supervisors may work out informal arrangements with employees who feel they cannot use or who do not have access to formal programs. In other instances, supervisors-who are responsible for output at the work unit level—may discourage the use of flexible scheduling because it interferes with production routines. Several studies have found that when employees have supervisors who support work-family balance, job satisfaction is higher and work-family conflict is lower (Bowen, 1998; Carlson and Perrewe, 1999; Greenberger et al., 1989; Thomas and Ganster, 1995). Eaton (2000) found work-family policies affected organizational commitment, but only to the extent that employees felt free to use them without negative consequences to their work lives (e.g., damage to career development opportunities or workplace relations).

The business case for flexible work practices is considerably less robust (Christensen and Staines, 1990; Gonyea and Googins, 1992; Lobel, 1999). Early studies of absenteeism found that it was lower among employees who used flextime (Kim and Campagna, 1981; McGuire and Liro, 1987; Ronen, 1984; Welch and Gordon, 1980). However, Swart (1985) found that alternative schedules improved absenteeism in only one (banking) out of three industries (not public utilities or insurance) studied. Zippo (1984) similarly found that in a study of gas and electric companies, 25 of the 125 companies used flex scheduling, but only 6 reported decreased 
absenteeism. Baltes et al. (1999) found that absenteeism was lower in 6 out of 8 studies of flextime, but only two out of five studies of compressed workweeks.

In one of the few longitudinal studies, Dalton and Mesch (1990) compared the absenteeism and turnover of employees in two divisions of one company: one with and one without flexible scheduling. Absenteeism fell significantly among employees eligible for flexible scheduling, but turnover was not affected. Other studies also have found limited or no support for the relationship between flexible scheduling practices and turnover or organizational commitment (Christensen and Staines, 1990; Dunham, Pierce and Castaneda, 1987; Pierce and Newstrom, 1983; Pierce et al., 1989). Thomas and Ganster (1995) found that employees with access to flexible scheduling had more control over managing work and family and higher job satisfaction, as well as lower work-family conflict, depression, and cholesterol. However, they did not find a significant relationship between these flexible practices and outcomes of interest to employers (i.e., absenteeism). They did not test the model with respect to employee turnover; however, the logic of the theoretical argument would extend to turnover intentions.

More recently, however, Grover and Crooker (1995) studied multiple family-responsive practices together and found that employees with access to more of these benefits showed greater organizational commitment and lower intention to leave. Their study supported the idea that corporate provision of programs symbolizes concern for employees, thereby positively influencing long-term attachment. Similarly, Lambert (2000) found that workers who considered the work-family benefits available to them to be useful were more likely to view their organizations as being supportive. Perceived usefulness of benefits was also related to organizational citizenship behavior. Scandura and Lankau (1997) found that workers with flexible work hours had higher organizational commitment. Perry-Smith and Blum (2000) found that work-family human resource bundles were associated with perceived organizational performance, but their measures do not allow for the disaggregation of dependent care benefits and flexible work arrangements. 
In sum, the literature on work-family policies and supervisor support suggests that dependent care policies have little systematic relationship to work-family outcomes or turnover. We nonetheless explore their relationship to outcomes of interest in this study because prior studies have generally examined dependent care only as an isolated practice. Here, we consider its importance in relation to flexible scheduling policies and other human resource practices. Prior research does suggest that flexible scheduling policies and supervisor support should be significantly related to outcomes of interest to employees and employers, leading to the following hypothesis.

H1: Employees who have more access to flexible scheduling practices or more supportive supervisors will have lower work-family conflict (negative spillover from work to family), more control over managing work and family demands, and lower probability of turnover.

\section{High Involvement HR Practices and Work-Family Outcomes}

The literature on high involvement HR practices has generally identified three dimensions of HR policies likely to improve employees' performance and reduce their probability of quitting: high relative skill requirements of jobs, HR incentives that induce motivation and attachment to the organization, and work designed to provide opportunities for employee discretion and team coordination (Appelbaum et al., 2000; Delery and Doty, 1996). When applied to production-level workers, these high involvement practices may be thought of as strategies to quasi-professionalize the non-managerial workforce. In the context of the current study of white collar employees, these measures of HR practices may be used to assess variation in the HR incentives and the design of work for an already highly skilled workforce.

\section{HR Incentives}

HR incentive practices typically designed to induce motivation and attachment to the organization include high relative pay and benefits, opportunities for training and career development, and implicit or explicit employment security (Appelbaum et al., 2000; Arthur, 1994). Historically, these practices have been identified as creating internal labor markets that buffer employees from the vicissitudes of competitive labor markets (Jacoby, 1985; Mitchell, 
1982; Osterman, 1987). Employees are less likely to quit because pay is high relative to what they can find on the external market and because they have opportunities for growth and development inside the organization. Empirical studies of compensation provide support for the inverse relationship between high relative pay and employee turnover (Leonard, 1987; Powell, Montgomery and Cosgrove, 1994; Shaw et al., 1998). Also, meta-analyses of research in organizational behavior (Cotton and Tuttle, 1986; Hom and Griffeth, 1995) demonstrate that turnover is lower among employees who perceive their employment to be secure, have higher relative pay levels, or higher pay satisfaction. Other studies have found that lower turnover is related to a cluster of employment practices that are conceptually similar to those identified in internal labor market theory (Arthur, 1994; Huselid, 1995).

Few studies, however, have examined the link between these HR incentive practices and work-family outcomes. In theory these practices are beneficial to employees and their families because they provide the kind of employment stability and income growth that families need (Raabe, 1990). High pay and benefits, employment security, and career development opportunities should create an environment in which parents view the employer as supportive and not in conflict with family needs and demands. In the context of the current study of dualcareer couples in small and medium-sized cities, organizationally-based employment security and career opportunities are particularly important because these couples must find two good jobs in a relatively small labor market. In this study, some of the employers were undergoing downsizing among the professional and managerial staff. Some prior studies have demonstrated the negative spillover of downsizing on families (Larson, Wilson and Beley, 1994; Voydanoff, 1990), and our field research suggests that the insecurity from downsizing did spill over and negatively affect family stability. The literature, in sum, suggests the following hypothesis:

H2: HR incentives of high relative pay, employment security, and career development opportunities will be positively associated with employees' perceptions of control over managing work and family and inversely related to work-family conflict and employees' intentions to quit. 


\section{The Design of Work}

Autonomy. A large body of literature has shown consistent positive relationships between intrinsically rewarding work and individual outcomes such as job satisfaction. From the large literature on job characteristics (Hackman and Oldham, 1980; Karasek and Theorell, 1990; Karasek, 1979; Lawler and Hall, 1970), for example, there is strong evidence that autonomy in decision making is associated with higher job satisfaction and lower propensity to quit (Hom and Griffeth, 1995). By extension, autonomy in decision-making should translate into greater employee ability to control decisions over when, where, and how to integrate work and family responsibilities.

Employers often worry, however, that greater individual autonomy or control for individual employees will simply undermine productivity. Some recent research by Bailyn and others, however, suggests otherwise (Bailyn, 1993a; Bailyn, Rapoport and Fletcher, 2000; Perlow, 1997). Bailyn's research group undertook intervention projects at three corporations in the early 1990s. In the instance of a team of product development engineers at Xerox, the work culture emphasized long hours and "face time" as a sign of commitment to work and career. Long meetings, documentation requirements, and the interference of supervisors in the day to day work of the engineers meant that the real work of product development often took place before or after daytime work hours. The long hours interfered with employees' home lives, and engendered a vicious circle of longer hours, high stress, and low productivity. The intervention led to a reexamination of time use and a redesign of work such that supervisors were not allowed to intervene in the work of the product development team during certain specified hours of the day. The design change increased the autonomy and control of development engineers over their productive workday schedule, which in turn led to a major increase in daytime productivity and a significant reduction in total work hours.

The work design literature along with other recent research, therefore, suggests that employees who enjoy greater autonomy at work will experience lower work-family conflict and more control over managing the work-family interface, and will show less likelihood of quitting 
their current employment. In addition, employees who have less flexibility at work-including longer work hours and more travel- are likely to report higher work-family conflict, less control over managing work and family demands, and more probability of quitting.

Team Collaboration and Coordination. The relationship between work-family conflict and other dimensions of work design are more ambiguous. For example, firms have increasingly adopted more collaborative or team-based forms of work organization to improve workplace quality, efficiency, and coordination. These collaborative forms are viewed as a central feature of high involvement systems. While there is considerable support for the idea that team collaboration and coordination do improve organizational performance (e.g., Cohen and Bailey, 1997; Cotton, 1993), there is little research on how these forms of work organization affect employees' ability to manage work and family.

On the one hand, the ability to collaborate or coordinate work with other colleagues may increase flexibility if co-workers are able to substitute for each other or establish norms of reciprocity in which they agree to help each other meet work and family demands. Three recent studies have found a positive relationship between team collaboration and ability to balance work and family. Bailyn (1993b) studied the productivity of customer service workers at a call center and found that 79 percent of the women and 53 percent of the men said that work interfered with family life-despite the fact that formal flextime scheduling was in place. The subsequent introduction of self-managed teams shifted control over work scheduling to team members, and absenteeism fell dramatically. Similarly, in a study of an insurance company, researchers found that underwriters suffered from low morale and high stress due to low productivity (Bailyn et al., 1998; Rayman et al., 1999). The researchers' solution was to work with employees to create a new work structure with greater coordination of work between the service and sales professionals. The team structure allowed sales to benefit from information gained by service staff and vice versa, and led to higher sales revenues. Employees reported higher morale, less stress, and more ability to control work and family life. A more quantitative study of teams, conducted among 4,000 blue collar workers in 40 manufacturing plants, found 
that team participation, communication, and decision-making autonomy were associated with positive work-family balance (Appelbaum, Berg and Kalleberg, 2000).

On the other hand, the demands of collaboration and group coordination may increase work hours or rigidities of work if they lead to time-consuming meetings or heightened peer group pressure. Some research shows that the peer group pressure in self-managed teams increases the imperative employees feel to be at work in order to avoid passing off duties to their peers (Barker, 1993). Among technical, professional, and managerial employees, for example, cross-functional coordination has become an increasingly important part of work as organizations have reduced numbers and levels of white collar employees. To the extent that coordination responsibilities have increased due to workforce reductions, coordination is likely to be associated with higher levels of work demands and structural rigidities.

Information Technology. A third area of work design that is rapidly changing is the use of information technology at home and at work, and this is also an area in which the likely impact on work and family integration is ambiguous. Because technology allows workers to bring work into the home more easily, it may have effects that are similar to those of telecommuting. However, that research has found very mixed outcomes because, while increasing flexibility, telecommuting also allows work to invade or spill over into home life more. Using a combination of qualitative and quantitative data to compare the experiences of 157 teleworkers and 89 traditional office workers, Hill and colleagues (1998) failed to demonstrate a consistent relationship between telecommuting and work/life balance. Similarly, on the one hand, the use of faxes, email, or computers at home for work-related activity can increase efficiency and allow employees to perform some tasks from home that they would otherwise have to do at work or through meetings. On the other hand, this ability to integrate work into the home may create a work atmosphere at home that is disruptive of family life. In sum, the literature suggests the following hypotheses regarding the design of work: 
H3a: Work designed to increase decision-making autonomy will be associated with lower work-family conflict, higher levels of control over managing work and family, and lower turnover intentions.

H3b: Hours of work and travel will be associated with increased work-family conflict, lower levels of control over managing work and family, and higher turnover intentions.

Finally, given the lack of prior research regarding the relationship between work-family outcomes and teams and technology use, we make no formal hypotheses about these relationships, but explore them in our analyses of the data.

\section{METHODS}

The research reported here is part of the larger 1998 Cornell Couples and Careers Study of dual-earner couples. Potential study participants were identified through seven large employers in upstate New York. In order to be eligible for participation in the study, respondents over 30 years of age had to be members of dual-earner couples (married or cohabiting) and currently employed; those under 30 only had to be employed. The seven participating organizations exemplify a variety of workplace cultures and practices and were chosen to represent four key economic sectors in upstate New York: manufacturing (2 organizations), health care ( 2 organizations), higher education ( 2 universities), and utilities (1 company). These employers sent their exempt (salaried) employees a letter inviting them to participate in the Cornell study. Those employees who were interested in participating and who believed they were eligible for the study returned response cards to the Cornell researchers and were included in our respondent pool. Due to employer concerns about confidentiality, the participating organizations did not provide access to information about those respondents who did not return response cards. Therefore, we are unable to accurately estimate our response rate to the initial mailing. However, of employees who did return the post card expressing initial interest, 75 percent completed the 1-hour telephone survey. Fifteen percent of those returning cards were not eligible to participate because they did not meet our criteria due to circumstances such as divorce or layoff. The spouses of participating employees were contacted on a separate 
occasion to answer the survey. Each respondent answered a core group of questions, and then was randomly administered one of three modules covering an additional subset of questions. The sample for the present study, which comprises one third of the overall Cornell Couples and Careers Study respondents, includes the participants who responded to the module on workplace characteristics. A full account of the research design and methods is found in Moen et al. (1999).

\section{Sample}

The sample for this study consists of 557 individuals, of whom $47 \%$ percent are male and $53 \%$ are female. The average age is 44 , and the range is 24 to 69 . Seventy-two percent have at least one child living at home. In order to capture family demands, respondents are grouped into life stages based upon the age of the youngest child living in the home. Seventy-two percent of respondents have preschool-aged children (under age 6), 24\% have school-aged children (ages 618 ), and $7 \%$ have adult children living in the home. Ninety-four percent of our sample is married or living in committed partnerships (respondents under $30 \mathrm{did}$ not have to be married or in a partnership). Of these, $83 \%$ are married to other survey respondents in this sample. (Please see the description of analyses for a discussion of the non-independence of the respondents.) All respondents are employed; $71 \%$ are managerial or professional employees, $14 \%$ are technical employees, and 15\% are administrative support staff. Ninety-two percent of the respondents are employed on a full-time as opposed to part-time basis (of the 47 part-time employees, 44 are women).

\section{Measures}

We used three measures of dependent variables: work-family conflict (negative spillover from work to family), employee control over work time, and intention to quit one's job. The first two measures capture day-to-day ability to manage time and commitments to work and family. Employee control is an eight-item scale (alpha =.76) adapted from Thomas and Ganster (1995). Using a scale of 1-5, employees were asked how much choice they have over their daily work schedule, weekly work schedule, their use of vacation and personal time, their ability to receive personal phone calls and email at work, the amount and timing of work that must be done at 
home in order to meet work demands, and the place in which they work (home versus regular work place). Work-family conflict is a two-item scale (alpha $=.54)$ developed by the John D. and Catherine T. MacArthur Foundation Network on Successful Midlife Development (MIDMAC). Items include "Your job makes you feel too tired to do the things that need attention at home" and "Job worries or problems distract you when you are at home." The third dependent variable is intention to turn over, measured by a scale score comprised of five items which asked whether respondents plan to stay with their present employer until retirement, how many more years they expect to stay, whether they have recently talked to colleagues or friends about looking for another job, whether they are actively looking for another job, and whether they are seriously considering quitting. The scale score takes on five values ranging from 0 to 4 , with 0 referencing a person who plans to retire from his or her current employer and 4 representing someone who does not plan to retire from the current employer and who is talking with friends, seriously considering quitting, and actively looking for a job. For this and other additive scales in our study, coefficient alpha was not computed ${ }^{1}$

Independent variables include two measures of formal and informal work-family support, three measures of human resource incentives, and five work design measures.

Formal and informal work-family support. Dependent care policies is an additive index that measures whether employees have access to five types of services: dependent care referral services, parenting seminars and assistance, child care center, and sick child care center. Flexible scheduling practices is an index measuring whether employees have access to five types of benefits relating to the flexible use of work time: paid family leave, personal/dependent care time (small increments of time off during work hours to attend to personal or family needs), flex time, telecommuting, and time off for volunteering. The variable takes on values ranging from 0 (have none) to 5 (have all five). We measured access to benefits rather than usage, following Thomas and Ganster (1995) and Grover and Crooker (1995), among others. Our rationale for measuring access is that the availability of work-family programs symbolize organizational concern for work and family balance and the availability of resources for employees as they need 
them. This type of employer concern for employee welfare is likely to be related to our dependent variables, which measure perceptions and intentionality to quit. Also, measuring usage has the potential problem of reverse causality, as those employees with the most difficult family situations may be the most likely to currently use programs.

Supervisor support is a 4-item shortened version of the scale developed by Shinn et al. (1989). Employees were asked how frequently in the past three months their supervisor had switched schedules to accommodate their family responsibilities, listened to their problems, juggled tasks or duties to accommodate their family responsibilities, and shared ideas or advice. Responses ranged from 1 (never) to 5 (very often). Two additional items, how frequently an employee's supervisor was critical of efforts to combine work and family and how frequently the supervisor held the employee's family responsibilities against him or her (both reverse coded) were not used in the scale because they failed to load on the same factor as the four items that were retained. The alpha reliability coefficient for the supervisor support scale is .68 .

Human resource incentives. Salary is measured with a single item which asks, "What is your annual salary from paid employment, including any bonuses, overtime, and/or commissions, before taxes and other deductions?" We applied a natural logarithmic transformation to this variable in order to normalize it. Job security asks respondents to report an answer to the following item: "Think of a scale of 0 to 100 , where 0 means you are certain you will lose your present job and 100 means you are certain you will be able to keep it. How certain is it that in the next couple of years you will be able to keep your job?" Career development benefits are measured by an additive index of three types of career support: a) education and training; b) tuition reimbursement; and c) career development services ( $3=$ have all three; $2=$ have two; $1=$ have one; $0=$ have none).

Work design measures. Decision-making autonomy is a scale adapted from the 1997 National Study of the Changing Workforce (Bond, Galinsky and Swanberg, 1998). Employees responded to three items: "I determine what I need to do in order to complete my assignments," "I am able to influence what procedures, tools, and material I use in doing my work," and "I am 
able to influence which specific tasks I am assigned to do." The response format was 1-5, where $1=$ strongly disagree and $5=$ strongly agree. The alpha reliability coefficient for this scale is .68 . Coordination is a 3-item additive scale adapted from Appelbaum et al. (2000); it asked how frequently employees coordinated with colleagues in their own department, colleagues outside of their department, and managers or supervisors in their department in order to accomplish their work tasks. The scale ( $1=$ daily to $5=$ never $)$ is reversed coded for this analysis. Flexible technology use is an additive index of six items that measure employees' use of email, beepers, cellular phones, or fax machines to communicate with work while at home or with home while at work and use of a portable computer or home computer to do work. Values range from 0 (use none) to 6 (use all). Work hours is a single-item measure which asks employees "On average, how many hours a week do you actually work, including any paid or unpaid extra hours that you put in beyond your official work week?" Travel is a dummy variable that measures whether or not the respondent is required to do overnight travel as a regular part of the job $(0=$ no, $1=y e s)$.

Control variables include individual and family characteristics. Gender is a dummy variable coded $1=$ women and $0=$ men. Gender is an important control not only because there are documented differences in the level and nature of work-family conflict experienced by women and men (Duxbury, Higgins and Lee, 1994; Duxbury and Higgins, 1991) but also because some research reports that women have higher levels of turnover than men. Causes for higher turnover among women include discrimination in pay and treatment, supervisory bias, lower status jobs, occupational segregation and dead-end jobs, and general lack of support and mentoring (Hom and Griffeth, 1995:241; Stroh, Brett and Reilly, 1996). Because children of varying ages place different types of demands on working parents, we include dummy variables to capture three different age groupings of children. Lifestage 1 indicates the presence or absence of preschool children (ages 0-5) in the home, lifestage 2 captures the presence of school-aged children ranging in age from 6-18, and lifestage 3 indicates whether respondents have adult children living in the home. Because past research has shown that individuals high in trait negative affectivity are more likely to experience significant levels of distress and dissatisfaction at all times and in any 
given situation (Watson and Clark, 1984; Watson and Slack, 1993), we control for this individual characteristic with a 5-item scale (affect). It is adapted from the John D. and Catherine T. MacArthur Foundation Network Study of Successful Midlife Development (MIDMAC). Employees rated (on a 5-point scale) how frequently in the past month they have felt in good spirits (reverse scored), so sad that nothing could cheer them up, restless or fidgety, nervous, or that everything was an effort. Coefficient alpha for this measure is .61. Age is self-reported and should be negatively related to turnover intentions. Temure measures the number of years employees have been in their jobs and was constructed from the job history variables administered as part of the Cornell Couples and Careers survey. We control for occupational type with occupational dummies that capture whether respondents are employed in a managerial/professional occupation, a technical occupation, or in administrative support work.

\section{Analysis}

In order to assess the relative effect of three blocks of predictors (formal and informal work-family support, HR incentives, and work design) on three outcomes (work-family conflict, employee control over work-family balance, and turnover intentions), we estimated a series of hierarchical regression equations. In a hierarchical procedure, single variables or sets of variables are entered into an equation in a specified hierarchical order, and upon the addition of each new set an $\mathrm{R}^{2}$ is determined (Cohen and Cohen, 1983). For all models, control variables were entered in step 1, work-family support variables in step 2 , human resource incentives in step 3, and work design variables in step 4.

We estimated all models for the full sample of men and women, and also for men and women separately. The models for the work-family conflict and control outcomes were estimated using ordinary least squares regression because these dependent variables are continuous and normally distributed. For the turnover models, however, we used ordered probit estimation because the dependent variable is measured on a 1-4 (multinomial) scale. Ordered or multinomial probits (logits) are estimated via a maximum likelihood technique. They estimate the probability of making a choice between items on a scale. ${ }^{2}$ 
Since this paper focuses on how individual employees use the benefits provided by their employers, the survey respondents are treated individually. This approach is appropriate because this study asks how job characteristics and access to individual benefits are related to individual employees' work-family conflict, perceptions of control over areas of work and family that have been shown to contribute to work-family conflict, and intentions to stay with their current employer. Only 15 percent of the sample include couples that work for the same employer, thus there is no reason to expect that the working conditions and benefits available to one spouse would be dependent on those of the other. In all multivariate analyses we used a Huber correction technique (Huber, 1967) because the sampling strategy (individuals in couples) violates ordinary least squares assumptions that observations are independent. Where cluster sampling exists, as in this case, the Huber technique assumes that observations are independent across groups, but not within groups. The alternative variance estimator takes into account the correlations within groups (couples), and thereby produces more robust standard errors.

\section{RESULTS}

In presenting our findings, we first report the variable means (Table 1) and correlation matrix (Table 2). We then briefly report the overall model fit for each dependent variable: workfamily conflict (Table 3), employee control over work and family (Table 4), and turnover intentions (Table 5). We then discuss the findings for each set of hypotheses for all three dependent variables: work-family policies (Hypothesis 1), HR incentives (Hypothesis 2), and work design elements (Hypothesis 3). Finally, we consider the similarities and differences in findings for women and men.

With respect to the overall means in the sample, our respondents report a moderate level of work-family conflict, a fairly high level of control over managing time commitments to work and family, and a low likelihood of turnover. The respondents are 44 years old on average, with a mean job tenure of just under 7 years. They report access to an average of 1.6 dependent care programs and 2.8 flexible scheduling policies. Respondents enjoy a modest amount of support 
from supervisors in managing work and family (2.6 average score out of a maximum of 5). Their average salary is $\$ 51,101$, with a standard deviation of $\$ 27,032$. They enjoy relatively high job security, 77.6 on a scale of $0-100($ standard deviation $=23.9)$. They work an average of 42 hours per week (standard deviation $=12$ ), and enjoy generally high job autonomy ( 4.1 out of a possible score of 5 , standard deviation $=0.7$ ).

Table 2 reports the correlation matrix. Most correlations are consistent with expected relationships. Work-family conflict is significantly positively related to turnover intentions; and employees' perception of control over managing work and family is significantly negatively related to turnover. Age and tenure are significantly negatively correlated with turnover intentions, indicating the importance of controlling for these dimensions of individual differences. Contrary to expectations, formal work-family policies are not significantly correlated with work-family conflict and with control, but supervisor support is negatively related to turnover intentions. Salary level is significantly positively correlated with both workfamily conflict and with employee control. This seeming contradiction is understandable in this sample of dual-career couples, but may not hold for other populations. Highly paid professional and managerial employees are likely to have greater demands on their time, and these interfere with managing work and family; at the same time, however, these professionals are likely to have greater opportunities to exert control in managing their time and schedules. Job security is negatively associated with both work-family conflict and turnover intentions. Some of the dimensions of work design appear to have more complex relationships with the outcomes of interest. Technology use, work hours, and travel are all positively related to both work-family conflict and employees' reported control over managing the work-family interface. We examine these in greater detail in the multivariate analyses below, particularly in order to explore whether there are similar or distinct patterns for men and women that are obscured in the correlational analysis.

Table 3 presents the results of the hierarchical regressions of work-family conflict. In the models that include both men and women, the base case controls for individual characteristics 
and explains 21.4 percent of the variance. The addition of the work-family policies, HR incentives, and work design variables on each subsequent step of the hierarchical regression procedure produces a modest but statistically significant increase in the $\mathrm{R}^{2}$. The work-family policies block of predictors explains an additional 1.2 percent of the variance. The HR incentives have the largest impact on the work-family conflict outcome, increasing the proportion of variance explained by 4 percent. The work design block increases the $\mathrm{R}^{2}$ by an additional 2.5 percent. The full model explains 29.1 percent in the variance of reported workfamily conflict.

Results for the employee control model are presented in Table 4. The base case explains 9.2 percent of the variance. The addition of the work-family policies variables does not produce an expected increase in the $\mathrm{R}^{2}$ figure. Human resource incentives, by contrast, increase the proportion of variance explained by 10 percent. The work design variables have the largest impact on the employee control outcome, increasing the proportion of variance explained by 17.8 percent. The percent of variance explained by the overall model is 32.4 .

Table 5 presents the results of the ordered probit models for turnover, also estimated in a hierarchical manner. The base case accounts for 9.8 of the variance explained. The human resource incentives block of predictors produces the largest increase in the likelihood-ratio $\chi^{2}$ statistic. The addition of the work-family policies and work design variables results in smaller yet still significant increases in the likelihood-ratio $\chi^{2}$ statistic.

\section{Work-Family Policies (Hypothesis 1)}

To consider each hypothesis, we compared the results across each of the three dependent variables: work-family conflict (negative spillover from work to family) (Table 3), control over managing work and family demands (Table 4), and employee probability of turnover (Table 5). Hypothesis 1 predicted that employees who have more access to flexible scheduling practices or more supportive supervisors would have lower work-family conflict, more control over managing work and family demands, and less probability of turnover. Contrary to expectations, flexible scheduling policies do not have an impact on either work-family conflict or employee 
control; however, access to flexible scheduling is predictive of lowered turnover intentions. For our sample of respondents, supervisor supportiveness of work-family integration is the most important component of work-family support. As expected, supervisor support is associated with lower levels of work-family conflict and turnover intentions. The coefficient for this measure is marginally significant in the employee control models; it appears that having a supportive supervisor also increases employees' perceptions of control. Thus, hypothesis 1 receives partial support. We also found that, as expected, dependent care benefits have no impact on these outcomes, except that the coefficients are marginally significant and positively related to employee control in one of the models. To explore this issue further, we re-estimated the equations using "usage" of benefits rather than "access to" dependent care benefits, but found no significant results from these analyses.

\section{HR Incentives (Hypothesis 2)}

Hypothesis 2 predicted that human resource incentives of high relative pay, employment security, and career development opportunities would be positively associated with employees' perceptions of control over managing work and family and inversely related to work-family conflict and employees' intentions to quit. At least one of the three coefficients in the HR incentives block of predictors is significant in each of the models. With regard to work-family conflict, employees with higher salaries are more likely to report experiencing negative spillover from work to family, while employees with high job security tend to report lower levels of conflict. Career development benefits have no impact on work-family conflict. Turning to employee control, we see that higher salary levels are associated with increased employee control, while neither career development benefits nor job security have an impact on this outcome. All three coefficients are significant in the turnover models. Salary and job security tend to decrease turnover intentions, while the presence of career development benefits is associated with an increased probability of turnover. Hypothesis 2 is therefore partially supported. 


\section{The Design of Work (Hypothesis 3)}

Hypothesis 3 a predicted that work designed to increase decision-making autonomy would be associated with lower work-family conflict, higher levels of control over managing work and family, and lower turnover intentions. Hypothesis $3 b$ predicted that hours of work and travel would be associated with increased work-family conflict, lower levels of control over managing work and family, and higher turnover intentions. Both of these hypotheses receive partial support. Examining the coefficients in the work-family conflict model, we see that neither autonomy nor travel has an effect, contrary to expectations. However, number of weekly work hours is positively related to work-family conflict, as predicted. Although no specific predictions were made regarding the influence of coordination with others and technology use, we see in Table 3 that both of these variables are associated with increased levels of reported spillover from work to family.

Turning to the model estimating perceptions of employee control (Table 4), all five variables in the work design block of predictors have a significant relationship with the dependent variable. We hypothesized that work hours and travel would decrease control, while

autonomy would increase it. These predictions are supported with the exception that the sign of the coefficient for travel is negative rather than positive as was hypothesized. We further find that technology use increases perceptions of control, while coordination with others decreases these perceptions. An examination of the coefficients in Table 5 shows that none of the work design variables is significantly associated with turnover intentions.

\section{Gender Differences}

There are several differences in the means of variables for women and men reported in Table 1. With respect to outcome variables, men reported higher levels of employee control over managing work and family demands. Women reported marginally higher levels of work-family conflict and marginally lower turnover intentions. With respect to individual characteristics, men in our sample are older and have longer job tenure. Men are also slightly more likely to be employed in technical positions, while women are marginally more likely to be employed in 
administrative support jobs (both differences significant at $p<.10$ ). There are no differences in the formal work-family benefits received by women and men or levels of supervisor support for managing work and family. There are more significant differences with respect to HR incentives and work design. Men have higher pay than women, but women report higher levels of job security. While men work longer hours, travel more, and use flexible technologies more, there are no differences in the level of reported decision autonomy in men's and women's jobs. Men report marginally higher levels of team coordination activity.

The coefficient for gender is significant in all of the multivariate models; thus we chose to analyze the male and female respondents in separate equations. For each dependent variable, the Chow test of differences in model estimates was significant. However, only a handful of independent variables account for the gender differences. Life stages 2 and 3 were significantly negatively related to women's perceived control over managing work and family, but not to men's perceptions of control. Life stage 2 captures the presence of school-aged children, while life stage 3 captures the present of adult children living at home. Not surprisingly, these findings suggest that it is women who bear the responsibility for transportation and coordination of the activities of school-aged and older children. Men in life stage 1, but not women, by contrast, are significantly more likely to report turnover intentions.

With regard to work-family supports, having a supportive supervisor tends to decrease women's level of reported work-family conflict, but does not have this effect for men. Supervisor support also lessens women's turnover intentions but does not affect men's, while flexible policies serve to depress men's plans to leave their employer but do not affect women's. There is little difference in the significance of the coefficients for the HR incentives variables for men and women across the three outcomes except that salary is a significant predictor of workfamily conflict for men only, and career development benefits are positively associated with turnover intentions for men but not for women. There are some interesting differences in the work design predictors of work-family conflict, with technology use and work hours tending to 
increase women's work-family conflict, and coordination with others positively influencing men's work-family conflict.

We also explored whether there were any cross-over effects between husbands and wives; that is, whether the work and employment conditions of one spouse influence the outcomes of the other spouse. To our surprise, we found almost no cross-over effects (the exception was that wives whose husbands earn higher salaries are less likely to report plans to leave their employers).

\section{DISCUSSION AND CONCLUSIONS}

In this paper we set out to examine whether a range of work-family policies and HR practices benefit firms as well as employees. We considered which sets of management practices influence work-family conflict and employees' control over managing work and family demands. We also examined whether these management practices influenced employees' propensity to quit. Turnover among high skilled technical, professional, and managerial employees is an important issue for management, particularly in the tight labor markets prevalent at the turn of the twenty-first century. If workplace practices can help employees integrate work and family demands, and in turn lower their voluntary quit rates, then employer investment in work-family practices is more cost-justified.

We analyzed three types of policies and practices: work-family supportive policies, including dependent care benefits, flexible scheduling, and supportive supervisors; HR incentives that contribute to income and employment security (salary, job security, and career development programs); and work design elements, including decision autonomy, coordination responsibilities, the use of flexible technology, work hours, and travel demands.

We found that all three sets of practices were significant predictors of the outcomes of interest for both employees and employers; and we found considerable consistency in the results across all three outcomes of interest. Several findings are noteworthy. First, work design characteristics were strong predictors of work-family conflict, and the strongest predictors of employees' perceptions of control or ability to manage work and family demands. Coordination 
responsibilities, technology use, and long work hours were associated with significantly higher work-family conflict. Coordination responsibilities and longer work hours also tended to decrease control over managing work and family. By contrast, decision-making autonomy and technology use increased employee control. Supportive supervision also was associated with lower work-family conflict and higher employee control. Job security predicted lower workfamily conflict. In addition, we found that flexible scheduling practices, supportive supervisors, job security, and high relative pay were all associated with lower turnover intentions, while career development benefits were associated with increased propensity to quit.

Second, there are some interesting paradoxical results as well. Using flexible technology to manage work and family demands, for example, is associated with higher work-family conflict but also higher perceptions of control. One logical interpretation of these findings is that while the use of technologies at home (faxes, e-mail, home computers, pagers) does afford people greater control in managing work and family demands, it is also disruptive of family life. This finding of the mixed blessings of technology is similar to what researchers have found with respect to telecommuting, which provides flexibility but also allows work to invade family space (Hill et al., 1998).

Another surprising finding is that travel demands are associated with greater control. Two interpretations are plausible. On the one hand, it is possible that overnight travel, at least in reasonable doses, allows people to get a break from family demands. Professionals, for example, often recount the virtues of long airline flights that allow them uninterrupted work time. On the other hand, our analysis may simply be picking up the fact that people who are most likely to travel are those at higher levels of the organization whose positions allow them more control over their work and family domains. Our study cannot sort out these alternative interpretations.

A third finding is that there are interesting similarities and differences between men and women. For both men and women, for example, three dimensions of work design had significant positive relationships to control over managing work and family: decision-making autonomy, the use of flexible technology, and whether overnight travel is a work requirement. Similarly, job 
security predicted lower work-family conflict and lower turnover probability for both men and women. And, not surprisingly, both men and women reported that having children in the household lowered their control over managing work and family. Several gender differences are noteworthy. Women's outcomes (work-family conflict and turnover) were significantly influenced by having a supportive supervisor, but men's were not. Men's turnover intentions, by contrast, were significantly lower when they had access to flexible scheduling. Women's reported control over managing work and family was lower than that of men. Finally, among women, flexible technology and work hours were significant predictors of work-family conflict, whereas for men, coordination responsibilities were significant.

While this analysis identifies some interesting relationships, we are limited in our causal inferences by the cross-sectional nature of the data. Also, all of the measures in our study are self-reports by respondents. There is a need to move beyond percept-percept methodology in research which seeks to link human resource practice to employee experience, but this is particularly challenging with regard to studying professional and managerial employees because of the intangible performance outcomes in knowledge work. The alpha coefficients on some of our scales are lower than we would like; unreliability in the measures may attenuate the strength of some regression coefficients. The generalizability of the findings is limited by sampling design, which includes a non-random sample of dual-earner couples in three cities in upstate New York. In addition, the individuals are primarily technical, professional, and managerial employees, thus limiting generalizations to lower skilled employees who lack the financial and human capital resources of this sample.

Our findings and conclusions, therefore, are suggestive of a future research agenda. We believe that this paper contributes to the work-family literature in several ways. First, rather than focusing on a limited set of formal or informal work-family policies alone, we have examined a more integrated model of factors that predict work-family conflict and employees' control over integrating work and family spheres. Few studies have examined new workplace innovations such as team coordination and flexible technology in relation to work-family issues. Our initial 
findings are suggestive, and show that the relationship between these workplace innovations and family life are significant, complex, and deserving of further study.

Second, we have provided empirical support for the idea that work-family policies and support as well as human resource practices characteristic of high involvement work systems have an effect on employees' intentions to stay with or leave their employer in addition to their reported level of work-family conflict and control over managing work and family demands. While prior research has demonstrated the importance of flextime policies and supportive supervisors, our findings suggest that work redesign provides a mechanism for positive outcomes for firms and employees.

An important theme in the work-family literature is that firms need to provide employees with flexible scheduling and work hours in order to facilitate work-family integration. We conclude that flexibility, per se, is not a complete solution. Rather, what matters is who has control of that flexibility. As we have demonstrated, some work practices provide employers with greater flexibility in meeting the demands of customers or clients, but reduce flexibility and control from the perspective of workers. Our preliminary findings suggest that cross-functional coordination responsibilities may be one of those dimensions of work. While such coordination, from a management perspective, helps companies reduce organizational layers and improve customer service, these increased responsibilities appear to have negative consequences for employees. Similarly, the use of flexible technology may increase employees' ability to get their work done, but at the expense of being on call at home at all hours. Thus, future research should more fully examine the meaning of workplace flexibility, and what kinds of flexibility are beneficial for employees as well as employers.

In sum, our results suggest that the most effective organizational responses to workfamily conflict and to employee propensity to quit are those that combine multiple elements, including family-supportive benefits, human resource incentives, and work design. None of these elements alone is enough to produce positive outcomes for both employees and employers. 


\section{REFERENCES}

Adams, G. A., and S. M. Jex. 1999. "Relationships between Time Management, Control, WorkFamily Conflict, and Strain." Journal of Occupational Health Psychology 4(1):72-77.

Appelbaum, E., T. Bailey, P. Berg, and A. L. Kalleberg. 2000. Manufacturing Advantage: Why High Performance Work Systems Pay Off. Ithaca, NY: Cornell University Press.

Appelbaum, E., P. Berg, and A. L. Kalleberg. 2000. "Balancing Work and Family: Effects of High Performance Work Systems and High Commitment Workplaces.".: Report to the U. S. Department of Labor.

Arthur, J. B. 1994. "Effects of Human Resource Systems on Manufacturing Performance and Turnover." Academy of Management Journal 37(3):670-687.

Bailyn, L. 1993a. Breaking the Mold: Women, Men, and Time in the New Corporate World. New York: Free Press.

—. 1993b. "Work-Family: A Catalyst for Change.". Cambridge, MA: Sloan School of Management, Massachusetts Institute of Technology.

Bailyn, L., R. Rapoport, and J. K. Fletcher. 2000. "Moving Corporations in the United States toward Gender Equity: A Cautionary Tale." In Organizational Change \& Gender Equity, edited by Linda Haas, Philip Hwang, and Graeme Russell, Pp. 167-179. Thousand Oaks, CA: Sage.

Bailyn, L., P. Rayman, M. Harvey, R. Krim, R. Read, F. Carre, J. Dickert, P. Joshi, and A. Martinez. 1998. "The Radcliffe-Fleet Project: Creating Work and Life Integration Solutions.". Cambridge: Radcliffe Public Policy Center.

Baltes, B. B., T. E. Briggs, J. W. Huff, J. A. Wright, and G. A. Neuman. 1999. "Flexible and Compressed Workweek Schedules: A Meta-Analysis of Their Effects on Work-Related Criteria." Journal of Applied Psychology 84(4):496-513.

Barker, J. R. 1993. "Tightening the Iron Cage: Concertive Control in Self-Managing Teams." Administrative Science Quarterly 38:408-437. 
Batt, R. 2000. "Managing Customer Services: Human Resource Practices, Quit Rates, and Sales Growth.”. Working Paper 00-07. Center for Advanced Human Resource Studies, Cornell University, Ithaca, NY.

Becker, B., and B. Gerhart. 1996. "The Impact of Human Resource Management on Organizational Performance: Progress and Prospects." Academy of Management Journal 39(4):779-801.

Becker, P., and P. Moen. 1999. "Scaling Back: Dual-Career Couples' Work-Family Strategies." Journal of Marriage and the Family 61(4):995-1007.

Bond, J. T., E. Galinsky, and J. E. Swanberg. 1998. "The 1997 National Study of the Changing Workforce.". New York: Families and Work Institute.

Bowen, G. L. 1998. "Effects of Leader Support in the Work Unit on the Relationship between Work Spillover and Family Adaptation." Journal of Family and Economic Issues $19(1): 25-52$.

Carlson, D. S., K. M. Kacmar, and L. J. Williams. 2000. "Construction and Initial Validation of a Multidimensional Measure of Work-Family Conflict." Journal of Vocational Behavior $56(2): 249-276$

Carlson, D. S., and P. L. Perrewe. 1999. "The Role of Social Support in the Stressor-Strain Relationship: An Examination of Work-Family Conflict." Journal of Management 25(4):513-540.

Cascio, W. F. 1991. Costing Human Resources: The Financial Impact of Behavior in Organizations. Boston: Kent.

Christensen, K. E., and G. Staines. 1990. "Flextime: A Viable Solution to Work-family Conflict?" Journal of Family Issues 11:455-476.

Cohen, J., and P. Cohen. 1983. Applied Multiple Regression/Correlation Analysis for the Behavioral Sciences. Hillsdale, NJ: Lawrence Erlbaum Associates.

Cohen, S., and D. Bailey. 1997. "What Makes Teams Work: Group Effectiveness Research from the Shop Floor to the Executive Suite." Journal of Management 23(3):239-290. 
Cooke, R. A., and D. M. Rousseau. 1984. "Stress and Strain from Family Roles and Work-Role Expectations." Journal of Applied Psychology 69(2):252-260.

Cortina, J. M. 1993. "What Is Coefficient Alpha? An Examination of Theory and Applications." Journal of Applied Psychology 78(1):98-104.

Cotton, J. L. 1993. Employee Involvement: Methods for Improving Performance and Work Attitudes. Newbury Park, CA: Sage.

Cotton, J. L., and J. M. Tuttle. 1986. "Employee Turnover: A Meta-Analysis and Review with Implications for Research." Academy of Management Review 11:55-70.

Dalton, D. R., and D. J. Mesch. 1990. "The Impact of Flexible Scheduling on Employee Attendance and Turnover." Administrative Science Quarterly 35:370-387.

Delery, J. E. 1998. Issues of Fit in Strategic Human Resource Management: Implications for Research. Human Resource Management Review, 8(3), 289-309.

Delery, J., and H. Doty. 1996. "Modes of Theorizing in Strategic Human Resource Management: Tests of Universalistic, Contingency, and Configurational Performance." Academy of Management Journal 39(4):802-835.

DeVellis, R. H. 1991. Scale Development. Newbury Park, CA: Sage.

Dunham, R. B., J. L. Pierce, and M. B. Castaneda. 1987. "Alternative Work Schedules: Two Field Quasi-Experiments." Personnel Psychology 40:215-243.

Duxbury, L., C. Higgins, and C. Lee. 1994. "Work-Family Conflict: A Comparison by Gender, Family Type, and Perceived Control." Journal of Family Issues 15(3):449-466.

Duxbury, L. E., and C. A. Higgins. 1991. "Gender Differences in Work-Family Conflict." Journal of Applied Psychology 76(1):60-74.

Eaton, S. 2000. "Work-Family Integration in the Biotechnology Industry: Implications for Firms and Employees." in Sloan School of Management. Cambridge: Massachusetts Institute of Technology.

Friedman, D. E. 1991. "Linking Work-Family Issues to the Bottom Line.". New York: The Conference Board. 
Frone, M. R., M. Russell, and M. L. Cooper. 1992. "Antecedents and Outcomes of Work-Family Conflict: Testing a Model of the Work-Family Interface." Journal of Applied Psychology $77: 65-78$

Glass, J. L., and S. B. Estes. 1997. "The Family Responsive Workplace." Annual Review of Sociology 23:289-313.

Goff, S. J., M. K. Mount, and R. L. Jamison. 1990. "Employer Supported Child Care, Workfamily Conflict, and Absenteeism: A Field Study." Personnel Psychology 43(4):793-809.

Gonyea, J., and B. Googins. 1992. "Linking the Worlds of Work and Family: Beyond the Productivity Trap." Human Resource Management 31(3):209-226.

Greenberger, E., W. Goldberg, S. Hamill, R. O'Neil, and C. K. Payne. 1989. "Contributions of a Supportive Work Environment to Parents' Well-Being and Orientation to Work." American Journal of Community Psychology 17(6):755-783.

Greenhaus, J. H., and N. J. Beutell. 1985. "Sources of Conflict between Work and Family Roles." Academy of Management Review 10:76-88.

Greenhaus, J. H., S. Parasuraman, C. S. Granrose, S. Rabinowitz, and N. J. Beutell. 1989. "Sources of Work-Family Conflict among Two-Career Couples." Journal of Vocational Behavior 34(2):133-153.

Grover, S. L., and K. J. Crooker. 1995. "Who Appreciates Family-Responsive Human Resource Policies: The Impact of Family-Friendly Policies on the Organizational Attachment of Parents and Non-Parents." Personnel Psychology 48:271-288.

Gutek, B. A., S. Searle, and L. Klepa. 1991. "Rational Versus Gender Role Explanations for Work-Family Conflict." Journal of Applied Psychology 76(4):560-568.

Hackman, J. R., and G. Oldham. 1980. Work Redesign. Reading, MA: Addison-Wesley.

Hill, E. J., B. C. Miller, S. P. Weiner, and J. Colihan. 1998. "Influences of the Virtual Office on Aspects of Work and Work/Life Balance." Personnel Psychology 51:667-683.

Hochschild, A. R. 1997. The Time Bind: When Work Becomes Home and Home Becomes Work. New York: Metropolitan Books. 
Hom, P. W., and R. W. Griffeth. 1995. Employee Turnover. Cincinnati: Southwestern College Publishing.

Huber, P. J. 1967. "The Behaviour of Maximum Likelihood Estimates under Non-Standard Conditions." Pp. 221-233 in Proceedings of the Fifth Berkeley Symposium on Mathematical Statistics and Probability.

Huselid, M. A. 1995. "The Impact of Human Resource Management Practices on Turnover, Productivity and Corporate Financial Performance." Academy of Management Journal $38(3): 635-672$.

Ichniowski, C., T. Kochan, D. Levine, C. Olson, and G. Strauss. 1996. "What Works at Work: Overview and Assessment." Industrial Relations 35(3):299-334.

Jacoby, S. 1985. Employing Bureaucracy. New York: Columbia University Press.

Karasek, R., and T. Theorell. 1990. Healthy Work: Stress, Productivity and the Reconstruction of Working Life. New York: Basic Books.

Karasek, R. A. 1979. "Job Demands, Job Decision Latitude, and Mental Strain: Implications for Job Redesign." Administrative Science Quarterly 24:285-308.

Kim, J., and A. Campagna. 1981. "Effects of Flexitime on Employee Attendance and Performance: A Field Experiment." Academy of Management Journal 24(4):729-741.

Kossek, E. E., and C. Ozeki. 1998. "Work-Family Conflict, Policies, and the Job-Life Satisfaction Relationship: A Review and Directions for Organizational Behavior Human Resources Research." Journal of Applied Psychology 83(2):139-149.

Lambert, S. J. 2000. "Added Benefits: The Link between Work-Life Benefits and Organizational Citizenship Behavior." Academy of Management Journal 43(5):801-815.

Larson, J. H., S. M. Wilson, and R. Beley. 1994. "The Impact of Job Insecurity on Marital and Family Relationships." Family Relations 43:138-143.

Lawler, E., and D. Hall. 1970. "Relationship of Job Characteristics to Job Involvement, Satisfaction, and Intrinsic Motivation." Journal of Applied Psychology 54:305-312. 
Leonard, J. S. 1987. "Carrots and Sticks: Pay, Supervision, and Turnover." Journal of Labor Economics 5:s136-s152.

Lobel, S. A. 1999. "Impacts of Diversity and Work-Life Initiatives in Organizations." In Handbook of Gender and Work, edited by Gary N. Powell. Thousand Oaks, CA: Sage.

McGuire, J. B., and J. R. Liro. 1987. "Absenteeism and Flexible Work Schedules." Public Personnel Management 16(1):47-59.

Milkovich, G. T., and L. Gomez. 1976. "Day Care and Selected Employee Work Behaviors." Academy of Management Journal 19(1):111-

Milkovich, G. T., and J. M. Newman. 1999. Compensation. Boston: Irwin/McGraw-Hill.

Miller, T. L. 1984. "The Effects of Employer-Sponsored Child Care on Employee Absenteeism, Turnover, Productivity, Recruitment or Job Satisfaction: What Is Claimed and What Is Known." Personnel Psychology 37(2):277-290.

Mitchell, O. 1982. "Fringe Benefits and Labor Mobility." Journal of Human Resources 17(2):286-298.

Moen, P., D. with Harris-Abbott, S. Lee, and P. Roehling. 1999. "The Cornell Couples and Careers Study.". Ithaca, NY: Cornell Employment and Family Careers Institute.

Moen, P., and Y. Yu. 1999. "Having It All: Overall Work/Life Success in Two-Earner Families." Research in the Sociology of Work 7:109-139.

Osterman, P. 1987. "Turnover, Employment Security, and the Performance of the Firm." In Human Resources and the Performance of the Firm, edited by M. Kleiner, M. Roomkin, and S. W. Salsburg. Madison, WI: Industrial Relations Research Association.

Parasuraman, S., J. H. Greenhaus, and C. S. Granrose. 1992. "Role Stressors, Social Support, and Well-Being among Two-Career Couples." Journal of Organizational Behavior 13(4):339-356.

Perlow, L. A. 1997. Finding Time: How Corporations, Individuals, and Families Can Benefit from New Work Practices. Ithaca, NY: Cornell University Press. 
Perry-Smith, J. E., and T. C. Blum. 2000. "Work-Family Human Resource Bundles and Perceived Organizational Performance." Academy of Management Journal 43(6):11071117.

Pierce, J., and J. Newstrom. 1983. "The Design of Flexible Work Schedules and Employee Responses: Relationships and Process." Journal of Occupational Behaviour 4:247-262.

Pierce, J. L., J. W. Newstrom, R. B. Dunham, and A. E. Barber. 1989. Alternative Work Schedules. Boston: Allyn and Bacon.

Powell, I., M. Montgomery, and J. Cosgrove. 1994. "Compensation Structure and Establishment Quit and Fire Rates." Industrial Relations 33(2):229-248.

Raabe, P. H. 1990. "The Organizational Effects of Workplace Family Policies." Journal of Family Issues 11(4):477-491.

Rayman, P., L. Bailyn, J. Dickert, and F. Carre. 1999. "Designing Organizational Solutions to Integrate Work and Life." Women in Management Review 14(5):164-176.

Ronen, S. 1984. Alternative Work Schedules: Selecting, Implementing and Evaluating. Homewood, IL: Dow Jones-Irwin.

Scandura, T. A., and M. J. Lankau. 1997. "Relationships of Gender, Family Responsibility and Flexible Work Hours to Organizational Commitment and Job Satisfaction." Journal of Organizational Behavior 18:377-391.

Shaw, J., J. Delery, G. D. Jenkins, Jr., and N. Gupta. 1998. "An Organization-Level Analysis of Voluntary and Involuntary Turnover." Academy of Management Journal 41(5):511-525.

Stroh, L. K., J. M. Brett, and A. H. Reilly. 1996. "Family Structure, Glass Ceiling, and Traditional Explanations for the Differential Rate of Turnover of Female and Male Managers." Journal of Vocational Behavior 49(1):99-118.

Swart, J. C. 1985. "Clerical Workers on Flexitime: A Survey of Three Industries." Personnel 62:40-44. 
Thomas, L. T., and D. C. Ganster. 1995. "Impact of Family-Supportive Work Variables on Work-Family Conflict and Strain: A Control Perspective." Journal of Applied Psychology 80(1):6-15.

U. S. Council of Economic Advisers. 2000. "The Annual Report of the Council of Economic Advisers.". Washington: United States Government Printing Office.

Voydanoff, P. 1990. "Economic Distress and Family Relations: A Review of the Eighties." Journal of Marriage and the Family 52:1099-1115.

Wallace, J. E. 1997. "It's About Time: A Study of Hours Worked and Work Spillover among Law Firm Lawyers." Journal of Vocational Behavior 50(2):227-248.

Watson, D., and L. A. Clark. 1984. "Negative Affectivity: The Disposition to Experience Aversive Emotional States." Psychological Bulletin 96:465-490.

Watson, D., and A. K. Slack. 1993. "General Factors of Affective Temperament and Their Relation to Job Satisfaction over Time." Organizational Behavior and Human Decision Processes 54(2): 181-202.

Welch, J. R., and D. Gordon. 1980. "Assessing the Impact of Flexitime on Productivity." MSU Business Horizons 23:61-65.

Youngblood, S. A., and K. Chambers-Cook. 1984. "Child Care Assistance Can Improve Employee Attitudes and Behavior." The Personnel Administrator 29(2):45-50.

Zippo, M. 1984. "Flexitime in the Utilities Industry." Personnel 61:42-44. 


\section{Table 1}

$\begin{array}{cccc}\text { All } & \text { Std. } & \text { Women } & \text { Men } \\ \text { Mean } & \text { Dev. } & \text { Mean } & \text { Mean }\end{array}$

\section{Dependent variables}

W/F conflict

Control over work-family

$2.750 \quad 0.624$

2.788

$2.708+$

Turnover intentions

$3.439 \quad 0.832$

3.309

$3.587 * * *$

0.572

1.037

0.500

$0.648+$

\section{Individual characteristics}

Female

Lifestage 1

Lifestage 2

Lifestage 3

Affect

Age

Tenure

Administrative

Technical

Professional/Managerial

$\begin{array}{rrrr}0.533 & 0.499 & 1.000 & 0.000 \\ 0.239 & 0.427 & 0.246 & 0.231 \\ 0.406 & 0.491 & 0.391 & 0.423 \\ 0.077 & 0.267 & 0.084 & 0.069 \\ 2.013 & 0.489 & 1.999 & 2.029 \\ 43.661 & 7.738 & 42.976 & 44.442 * \\ 6.762 & 6.885 & 6.023 & 7.607 * * \\ 0.124 & 0.330 & 0.141 & 0.104+ \\ 0.144 & 0.351 & 0.125 & 0.165+ \\ 0.732 & 0.443 & 0.734 & 0.731\end{array}$

\section{Work-family policies}

$\begin{array}{lllll}\text { Dependent care } & 1.598 & 1.329 & 1.559 & 1.642 \\ \text { Flexible policies } & 2.797 & 1.511 & 2.822 & 2.769 \\ \text { Supervisor support } & 2.637 & 0.979 & 2.698 & 2.567\end{array}$

\section{HR incentives}

Annual salary

Annual salary (ln)

Career benefits

Job security

$\begin{array}{rr}51,545 & 26,632 \\ 10.693 & 0.625\end{array}$

10.693

2.215

77.643

0.997

23.898

42,675

10.481

2.185

79.599

$61,676 * * *$

$10.934 * * *$

2.250

$75.408 *$

\section{Work design}

\section{Autonomy}

Coordination

Technology

Work hours

Travel

$\begin{array}{rr}4.107 & 0.672 \\ 12.939 & 2.058 \\ 2.485 & 1.622 \\ 42.278 & 11.358 \\ 0.443 & 0.497\end{array}$

4.114

12.788

2.337

39.128

0.357
4.099

$13.112+$

$2.654 *$

$45.877 * * *$

$0.542 * * *$

$$
* * *=\text { p. }<.001 ; * *=\text { p. }<.01 ; *=\mathrm{p}<.05 ;+=\mathrm{p}<.10
$$


Table 2:

Correlation Matrix

\begin{tabular}{|c|c|c|c|c|c|c|c|c|c|c|}
\hline & 1 & 2 & 3 & 4 & 5 & 6 & 7 & 8 & 9 & 10 \\
\hline $1 \mathrm{~W} / \mathrm{F}$ conflict & 1.000 & & & & & & & & & \\
\hline 2 Control over work-family & 0.058 & 1.000 & & & & & & & & \\
\hline 3 Turnover intentions & $0.115^{*}$ & $-0.117 *$ & 1.000 & & & & & & & \\
\hline 4 Female & 0.064 & $-0.167 *$ & -0.072 & 1.000 & & & & & & \\
\hline 5 Lifestage 1 & 0.028 & 0.005 & $0.155 *$ & 0.018 & 1.000 & & & & & \\
\hline 6 Lifestage 2 & -0.036 & -0.070 & -0.033 & -0.033 & $-0.463 *$ & 1.000 & & & & \\
\hline 7 Lifestage 3 & -0.068 & $-0.086 *$ & -0.046 & 0.028 & $-0.162 *$ & $-0.239 *$ & 1.000 & & & \\
\hline 8 Affect & $0.409 *$ & 0.010 & $0.116 *$ & -0.031 & 0.013 & 0.041 & -0.063 & 1.000 & & \\
\hline 9 Age & -0.081 & $0.104 *$ & $-0.271 *$ & $-0.095 *$ & $-0.416 *$ & 0.031 & $0.219 *$ & $-0.192 *$ & 1.000 & \\
\hline 10 Tenure & $-0.096 *$ & 0.016 & $-0.242 *$ & $-0.115 *$ & $-0.119 *$ & -0.048 & 0.021 & -0.036 & $0.339 *$ & 1.000 \\
\hline 11 Administrative & $-0.164 *$ & $-0.172 *$ & -0.004 & 0.057 & -0.044 & 0.078 & -0.007 & 0.006 & -0.060 & 0.009 \\
\hline 12 Professional & 0.024 & -0.067 & 0.044 & -0.058 & $0.131 *$ & -0.026 & -0.061 & 0.016 & $-0.103 *$ & 0.041 \\
\hline 13 Dependent care & 0.040 & 0.080 & 0.012 & -0.031 & 0.027 & 0.055 & -0.029 & 0.073 & -0.006 & 0.000 \\
\hline 14 Flexible policies & 0.055 & 0.047 & -0.061 & 0.017 & -0.003 & -0.003 & -0.032 & 0.037 & 0.051 & 0.009 \\
\hline 15 Supervisor support & -0.081 & 0.024 & $-0.103 *$ & 0.067 & 0.082 & -0.071 & 0.008 & 0.052 & $-0.119 *$ & -0.006 \\
\hline 16 Annual salary (ln) & $0.193 *$ & $0.320 *$ & -0.071 & $-0.362 *$ & -0.017 & -0.043 & -0.057 & 0.029 & $0.150 *$ & $0.113 *$ \\
\hline 17 Career benefits & 0.071 & $0.087 *$ & 0.043 & -0.033 & -0.066 & -0.003 & -0.015 & 0.030 & 0.072 & 0.052 \\
\hline 18 Job security & $-0.206 *$ & -0.030 & $-0.215 *$ & $0.088 *$ & 0.062 & -0.059 & 0.018 & $-0.138 *$ & 0.012 & 0.072 \\
\hline 19 Autonomy & $-0.099 *$ & $0.272 *$ & -0.074 & 0.011 & -0.006 & -0.014 & 0.009 & $-0.138 *$ & 0.064 & 0.017 \\
\hline 20 Coordination & $0.148 *$ & -0.034 & 0.044 & -0.079 & -0.055 & 0.037 & 0.022 & 0.052 & 0.000 & -0.052 \\
\hline 21 Technology & $0.209 *$ & $0.398 *$ & $0.104 *$ & $-0.098 *$ & 0.074 & 0.012 & $-0.111 *$ & $0.106 *$ & $-0.112 *$ & $-0.117 *$ \\
\hline 22 Work hours & $0.197 *$ & $0.155 *$ & 0.037 & $-0.297 *$ & -0.079 & -0.068 & -0.029 & 0.067 & 0.073 & 0.016 \\
\hline 23 Travel & $0.120 *$ & $0.314 *$ & 0.022 & $-0.186 *$ & -0.051 & 0.013 & -0.069 & 0.059 & 0.028 & 0.025 \\
\hline
\end{tabular}

$* * *=$ p. $<.001 ; * *=$ p. $<.01 ; *=\mathrm{p}<.05 ;+=\mathrm{p}<.10$ 
Table 2:

Correlation Matrix

$1 \mathrm{~W} / \mathrm{F}$ conflict

11

12

13

14

15

16

17

18

19

20

21

2 Control over work-family

3 Turnover intentions

4 Female

5 Lifestage 1

6 Lifestage 2

7 Lifestage 3

8 Affect

9 Age

10 Tenure

11 Administrative

12 Professional

13 Dependent care

14 Flexible policies

15 Supervisor support

16 Annual salary (ln)

17 Career benefits

18 Job security

19 Autonomy

20 Coordination

21 Technology

22 Work hours

23 Travel

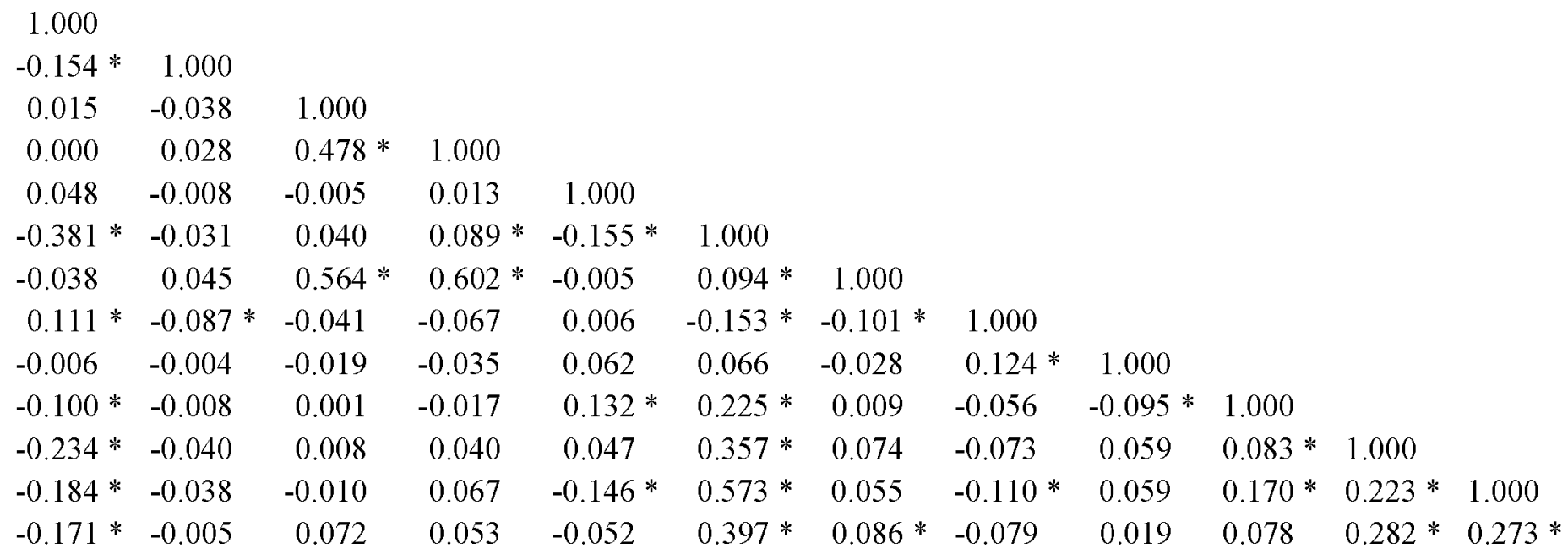


Table 3: Predictors of Work-family Conflict (Hierarchical Regression)

\begin{tabular}{|c|c|c|c|c|c|c|c|c|c|c|c|c|}
\hline & & & & All Respond & ents & & & & Women & & Men & \\
\hline & Coef. & Std. beta & Coef. & Std. beta & Coef. S & Std. beta & Coef. & Std. beta & Coef. & Beta & Coef. & Beta \\
\hline Individual & & & & & & & & & & & & \\
\hline Gender & 0.100 & $0.080 *$ & 0.106 & $0.084 *$ & 0.190 & $0.152 * * *$ & 0.206 & $0.165 * * *$ & & & & \\
\hline Lifestage 1 & -0.041 & -0.028 & -0.039 & -0.027 & -0.015 & -0.010 & 0.011 & 0.008 & 0.002 & 0.002 & 0.011 & 0.007 \\
\hline Lifestage 2 & -0.092 & $-0.073+$ & -0.099 & $-0.078+$ & -0.084 & -0.066 & -0.077 & -0.061 & -0.146 & $-0.116+$ & -0.031 & -0.024 \\
\hline Lifestage 3 & -0.168 & -0.072 & -0.159 & -0.068 & -0.119 & -0.051 & -0.107 & -0.046 & -0.153 & -0.069 & -0.109 & -0.044 \\
\hline Affect & 0.529 & $0.414 * * *$ & 0.531 & $0.416 * * *$ & 0.503 & $0.394 * * *$ & 0.478 & $0.375 * * *$ & 0.434 & $0.328 * * *$ & 0.556 & $0.452 * * *$ \\
\hline Age & 0.003 & 0.032 & 0.001 & 0.017 & 0.000 & 0.004 & 0.002 & 0.022 & 0.008 & 0.091 & -0.005 & -0.064 \\
\hline Tenure & -0.008 & $-0.087 *$ & -0.007 & $-0.082 *$ & -0.007 & $-0.083 *$ & -0.005 & -0.058 & 0.000 & 0.000 & -0.010 & $-0.115 *$ \\
\hline Administrative & -0.311 & $-0.164 * * *$ & -0.304 & $-0.160 * * *$ & -0.158 & $-0.083 *$ & -0.135 & $-0.071+$ & -0.116 & -0.066 & -0.142 & -0.069 \\
\hline Professional & 0.002 & 0.001 & -0.003 & -0.002 & 0.011 & 0.006 & 0.025 & 0.014 & 0.022 & 0.012 & 0.039 & 0.023 \\
\hline Work-family policies & & & & & & & & & & & & \\
\hline Dependent care & & & 0.000 & 0.000 & -0.007 & -0.015 & -0.002 & -0.004 & -0.005 & -0.011 & 0.006 & 0.011 \\
\hline Flexible policies & & & 0.015 & 0.037 & -0.003 & -0.007 & -0.003 & -0.006 & -0.009 & -0.023 & 0.020 & 0.048 \\
\hline Supervisor support & & & -0.066 & $-0.103 * *$ & -0.053 & $-0.084 *$ & -0.064 & $-0.101 *$ & -0.108 & $-0.178 * * *$ & -0.012 & -0.017 \\
\hline HR incentives & & & & & & & & & & & & \\
\hline Annual salary $(\ln )$ & & & & & 0.174 & $0.174 * * *$ & 0.061 & 0.061 & -0.013 & -0.015 & 0.206 & $0.152 *$ \\
\hline Career benefits & & & & & 0.029 & 0.047 & 0.022 & 0.035 & -0.016 & -0.026 & 0.032 & 0.049 \\
\hline Job security & & & & & -0.003 & $-0.121 * *$ & -0.003 & $-0.118 * * *$ & -0.003 & $-0.116 *$ & -0.003 & $-0.124 *$ \\
\hline Work design & & & & & & & & & & & & \\
\hline Autonomy & & & & & & & -0.033 & -0.035 & -0.007 & -0.008 & -0.046 & -0.050 \\
\hline Coordination & & & & & & & 0.030 & $0.098 *$ & 0.013 & 0.045 & 0.052 & $0.168 * *$ \\
\hline Technology & & & & & & & 0.039 & $0.101 *$ & 0.053 & $0.137 *$ & 0.024 & 0.063 \\
\hline Work hours & & & & & & & 0.005 & $0.098 *$ & 0.007 & $0.136 *$ & 0.002 & 0.033 \\
\hline Travel & & & & & & & 0.014 & 0.011 & 0.109 & 0.085 & -0.109 & -0.086 \\
\hline Constant & 1.672 & $* * *$ & 1.845 & $* * *$ & 0.224 & & 0.820 & & 1.823 & & -0.793 & \\
\hline Number of obs & 557 & & 557 & & 557 & & 557 & & 297 & & 260 & \\
\hline F statistic & 15.620 & $* * *$ & 12.450 & $* * *$ & $12.830 *$ & $* * *$ & 10.520 & $* * *$ & 5.87 & $* * *$ & 7.65 & $: * *$ \\
\hline R-squared & 0.214 & & 0.225 & & 0.265 & & 0.291 & & 0.287 & & 0.377 & \\
\hline Chg R-squared & & & 0.012 & & 0.040 & & 0.025 & & & & & \\
\hline F for Chg. R2 & & & 2.687 & & $9.850 *$ & $* * *$ & 3.868 & $* * *$ & & & & \\
\hline
\end{tabular}
$* * *=$ p. $<.001 ; * *=$ p. $<.01 ; *=\mathrm{p}<.05 ;+=\mathrm{p}<.10$. 
Table 4: Predictors of Employee Control Over Managing Work and Family (Hierarchical Regression)

\begin{tabular}{|c|c|c|c|c|c|c|c|c|c|c|c|c|}
\hline & & & All Resp & ondents & & & & & Women & & Men & \\
\hline & Coef. & Beta & Coef. & Beta & Coef. & Beta & Coef. & Beta & Coef. & Beta & Coef. & Beta \\
\hline Individual Char. & & & & & & & & & & & & \\
\hline Gender & -0.259 & $-0.156 * * *$ & -0.261 & $-0.157 * * *$ & -0.124 & $-0.074+$ & -0.145 & $-0.087 *$ & & & & \\
\hline Lifestage 1 & -0.040 & -0.020 & -0.055 & -0.028 & -0.044 & -0.023 & -0.075 & -0.038 & -0.006 & -0.003 & -0.136 & -0.075 \\
\hline Lifestage 2 & -0.193 & $-0.114 *$ & -0.200 & $-0.118 *$ & -0.167 & $-0.099 *$ & -0.200 & $-0.118 * *$ & -0.277 & $-0.156^{*}$ & -0.143 & -0.092 \\
\hline Lifestage 3 & -0.441 & $-0.142 * *$ & -0.445 & $-0.143 * *$ & -0.375 & $-0.120^{*}$ & -0.295 & $-0.095 *$ & -0.384 & $-0.123^{*}$ & -0.239 & -0.079 \\
\hline Affect & 0.041 & 0.024 & 0.028 & 0.017 & 0.017 & 0.010 & 0.031 & 0.018 & 0.106 & 0.057 & -0.063 & -0.043 \\
\hline Age & 0.012 & $0.113 *$ & 0.012 & $0.116 *$ & 0.010 & $0.098 *$ & 0.012 & $0.115 *$ & 0.020 & $0.167 * *$ & 0.003 & 0.031 \\
\hline Tenure & -0.005 & -0.039 & -0.005 & -0.041 & -0.007 & -0.058 & -0.003 & -0.028 & -0.012 & -0.083 & 0.004 & 0.042 \\
\hline Administrative & -0.414 & $-0.164 * * *$ & -0.421 & $-0.167 * * *$ & -0.188 & -0.074 & -0.098 & -0.039 & 0.009 & 0.004 & -0.244 & $-0.097+$ \\
\hline Professional & -0.230 & $-0.097 *$ & -0.221 & -0.093 & -0.154 & $-0.065+$ & -0.125 & -0.053 & 0.072 & 0.027 & -0.319 & $-0.155 * *$ \\
\hline Work-family polici & & & & & & & & & & & & \\
\hline Dependent care & & & 0.047 & $0.074+$ & 0.040 & 0.063 & 0.042 & 0.067 & 0.036 & 0.057 & 0.068 & $0.116+$ \\
\hline Flexible policies & & & 0.002 & 0.005 & -0.021 & -0.038 & -0.010 & -0.019 & -0.024 & -0.041 & -0.012 & -0.023 \\
\hline Supervisor support & & & 0.042 & 0.049 & 0.067 & $0.079+$ & 0.032 & 0.038 & 0.055 & 0.064 & 0.007 & 0.008 \\
\hline HR incentives & & & & & & & & & & & & \\
\hline Annual salary (ln) & & & & & 0.340 & $0.255 * * *$ & 0.165 & $0.124 *$ & 0.116 & 0.089 & 0.204 & $0.124+$ \\
\hline Career benefits & & & & & 0.036 & 0.043 & 0.008 & 0.010 & 0.003 & 0.003 & -0.004 & -0.005 \\
\hline Job security & & & & & 0.001 & 0.024 & 0.000 & -0.009 & 0.000 & -0.006 & 0.000 & 0.000 \\
\hline Work design & & & & & & & & & & & & \\
\hline Autonomy & & & & & & & 0.292 & $0.236 * * *$ & 0.368 & $0.283 * * *$ & 0.208 & $0.184 * * *$ \\
\hline Coordination & & & & & & & -0.032 & $-0.078 *$ & -0.023 & -0.054 & -0.041 & $-0.108+$ \\
\hline Technology & & & & & & & 0.152 & $0.296 * * *$ & 0.142 & $0.262 * * *$ & 0.153 & $0.328 * * *$ \\
\hline Work hours & & & & & & & -0.006 & $-0.081+$ & -0.004 & -0.052 & -0.005 & -0.070 \\
\hline Travel & & & & & & & 0.281 & $0.168 * * *$ & 0.301 & $0.167 * *$ & 0.263 & $0.171 * *$ \\
\hline Constant & 3.201 & $* * *$ & 3.031 & $* * *$ & -0.743 & & 0.163 & & -0.398 & & 0.805 & \\
\hline Sample & 557 & & 557 & & 557 & & 557 & & 297 & & 260 & \\
\hline F statistic & 6.320 & $* * *$ & 5.210 & $* * *$ & 5.990 & $* * *$ & 17.340 & $* * *$ & 6.830 & $* * *$ & 6.500 & $* * *$ \\
\hline R-squared & 0.092 & & 0.100 & & 0.146 & & 0.324 & & 0.319 & & 0.340 & \\
\hline Chg.R-squared & & & 0.008 & & 0.045 & & 0.178 & & & & & \\
\hline F for Chg. R2 & & & 1.6497 & & 9.59656 & $* * *$ & 47.665 & $* * *$ & & & & \\
\hline
\end{tabular}

$* * *=\mathrm{p} .<.001 ; * *=\mathrm{p} .<.01 ; *=\mathrm{p}<.05 ;+=\mathrm{p}<.10$ 
Table 5: Predictors of Turnover Intentions (Ordered Probit Models)

\begin{tabular}{|c|c|c|c|c|c|c|}
\hline \multirow{3}{*}{$\begin{array}{l}\text { Individual Char. } \\
\text { Gender }\end{array}$} & \multicolumn{3}{|c|}{ All Respondants } & \multirow{3}{*}{$\begin{array}{l}\text { Coef. } \\
-0.300 * *\end{array}$} & \multirow{3}{*}{$\begin{array}{c}\text { Women } \\
\text { Coef. }\end{array}$} & \multirow{3}{*}{$\begin{array}{l}\text { Men } \\
\text { Coef. }\end{array}$} \\
\hline & Coef. & Coef. & Coef. & & & \\
\hline & $-0.288 * *$ & $-0.279 * *$ & $-0.309 * *$ & & & \\
\hline Lifestage 1 & 0.241 & 0.261 & $0.360 *$ & $0.361 *$ & -0.251 & $0.850 * * *$ \\
\hline Lifestage 2 & 0.059 & 0.031 & 0.007 & -0.013 & -0.132 & 0.051 \\
\hline Lifestage 3 & -0.023 & -0.013 & -0.059 & -0.022 & -0.159 & -0.024 \\
\hline Affect & 0.133 & 0.137 & 0.074 & 0.054 & 0.148 & -0.063 \\
\hline Age & $-0.039 * * *$ & $-0.042 * * *$ & $-0.044 * * *$ & $-0.041 * * *$ & $-0.045 * * *$ & $-0.042 * *$ \\
\hline Tenure & $-0.060 * * *$ & $-0.061 * * *$ & $-0.060 * * *$ & $-0.058 * * *$ & $-0.092 * * *$ & $-0.038 *$ \\
\hline Administrative & -0.019 & 0.016 & -0.151 & -0.109 & -0.080 & -0.289 \\
\hline Professional & 0.051 & 0.042 & -0.094 & -0.083 & 0.299 & -0.378 \\
\hline \multicolumn{7}{|c|}{ Work-family policies } \\
\hline Dependent care & & 0.045 & 0.012 & 0.016 & 0.088 & -0.026 \\
\hline Flexible policies & & -0.058 & $-0.128 *$ & $-0.126 *$ & -0.061 & $-0.174 *$ \\
\hline Supervisor support & & $-0.201 * * *$ & $-0.211 * * *$ & $-0.231 * * *$ & $-0.328 * * *$ & -0.149 \\
\hline \multicolumn{7}{|l|}{ HR incentives } \\
\hline Annual salary (ln) & & & $-0.346 * *$ & $-0.502 * * *$ & $-0.408 *$ & $-0.525 *$ \\
\hline Career benefits & & & $0.189 *$ & $0.173 *$ & 0.040 & $0.270 *$ \\
\hline Job security & & & $-0.013 * * *$ & $-0.013 * * *$ & $-0.008 *$ & $-0.019 * * *$ \\
\hline \multicolumn{7}{|l|}{ Work design } \\
\hline Autonomy & & & & -0.028 & -0.008 & -0.106 \\
\hline Coordination & & & & 0.027 & 0.011 & -0.006 \\
\hline Technology & & & & 0.060 & $0.106+$ & 0.028 \\
\hline Work hours & & & & 0.001 & -0.007 & 0.008 \\
\hline Travel & & & & 0.186 & 0.277 & 0.062 \\
\hline \multicolumn{7}{|l|}{ Constant } \\
\hline Sample & 488 & 488 & 488 & 488 & 252 & 236 \\
\hline Wald Chi2 & $70.930 * * *$ & $91.370 * * *$ & $159.450 * * *$ & $168.240 * * *$ & $81.170 * * *$ & $90.470 * * *$ \\
\hline Pseudo R2 & 0.098 & 0.111 & 0.149 & 0.154 & 0.174 & 0.185 \\
\hline
\end{tabular}



${ }^{1}$ Coefficient alpha is an estimate of internal consistency, which refers to the degree of interrelatedness among the items in a scale. Our turnover, dependent care policies, flexible scheduling practices, technology use, and team coordination indices are additive scales that measure a number of different elements which, in sum, provide an index relevant to the variable of interest. An index is made up of items that "determine the level of a construct," as opposed to a scale, which assumes that responses to items are "caused by an underlying construct" (DeVellis, 1991:9). We do not assume (as with our other scales) that the items in the indices are caused by an underlying construct and are equivalent measures of that construct. Rather, we assume that the level of the construct is determined by the sum of responses of non-equivalent items. Standardized alpha is therefore inappropriate to the extent that more than one factor is responsible for the correlations among each set of items (Cortina, 1993; Delery, 1998).

${ }^{2}$ The logit and probit models differ in their assumptions about the error term. Logit models assume that the error terms are independently and identically distributed; this means that it does not distinguish between alternatives that are close substitutes. Probit models assume that error terms are distributed multivariate-normally, allowing error terms to be correlated across alternatives. This allows for more accurate distinctions across similar alternatives. We tested both logit and probit models in our study, and did not find significant differences in coefficients or levels of significance. We report probit results here. 